\title{
EMOTIONAL COMPETENCIES AND PERSONALITY TRAITS OF MANAGERS IN MODERN AGROBUSINESS
}

\author{
Gordana Nikić1, Ljubiša Stamatovič ${ }^{2}$ Azra Sućeska ${ }^{3}$
}

\begin{abstract}
The main goal of this paper is to determine the difference between high-level and midlevel managers in agribusiness compared to lower managerial positions in terms of personality traits and emotional intelligence. The research covered 240 respondents from Serbia. The structure of the sample is heterogeneous, consisting of employees and managers of both genders and various ages. This paper presents the results relating to the permanent staff of 125 managers in the Mercator Group trade chain of food industry. To estimate emotional intelligence Questionnaire of emotional competence (Takšić, Moharić, Munjas, 2006) was used, and Personality Questionnaire was used for estimating dominant personality traits, ZKPQ (Zuckerman, 2002). The results indicate that the higher-level managers show a higher level of emotional intelligence in perceiving and understanding emotions, regulation and management of emotions, and also their personality trait called Activity is higher than in any other group of respondents. The respondents who are in lower managerial positions show higher sociability in relation to the higher-level managers.
\end{abstract}

Keywords: managers, agribusiness, emotional intelligence

JEL:Q16, M24

\section{Introduction}

The present moment of agribusiness development is very dynamic. Modern organizations are trying to find ways to increase productivity and competitiveness on the market in the conditions of sharp competition, open market and globalization, and, on the other hand, consumers are increasingly aware of the importance of food for life and health. The privatization of food sector has made a number of changes which all actors are faced

1 Gordana Nikić Ph.D., Assistant Professor, Singidunum University, Faculty of Tourism and Hospitality Management, Kumodraška Street no. 261a, 11000 Belgrade, Serbia, Phone: +381 63 7365817, E-mail: gnikic@singidunum.ac.rs

2 Ljubiša Stamatović M.A., M.Sc., Ph.D. candidate, Assistant, Union University, Belgrade Banking Academy, Zmaj Jovina Street no. 3, 11000 Belgrade, Serbia, +381 612453 486, E-mail: ljubisastamatovic@gmail.com

3 Azra Sućeska Ph.D., Assistant Professor, SUSU-SOUTH Ural State University, Chelyabinsk, Russia, +381 66 234304, E-mail: azra.hanic@bba.edu.rs

EP 2017 (64) 1 (97-111) 
with. According to these authors, the competition in the process of trade liberalization brings sharp competition so that agricultural business should develop a new conceptof management and marketing in order to provide higher production and sales, based on market and economic conditions (Cvijanovic, Trandafilović, Imamovic, 2013). On the other hand, end users are increasingly aware of the importance of healthy food, which brings new challenges and great opportunities for eco-organic production (Cvijanovic, Dozet, Cvijanovic, 2013).

Despite the fact that the management of agribusiness, as well as of the other fields of business, is mostly occupied with basic issues - how to best use the resources in the uncertain business environment, there are more and more authors who speak about the importance of so-called "soft variables" that include people, knowledge, skills, abilities (Repar, Njari, Par, 2012).

In the business environment of food industry, in the area of management structures, high professionalism and innovativeness are at the forefront, but also high capacity for coordination of personnel, which raises questions of interpersonal skills and personality traits of managers. The man, besides performing physical activities and intellectual operations in the workplace, also takes certain social roles, or looks for his true role, as is the case for managerial jobs. For this reason, an individual needs corresponding personality traits and interpersonal skills (Čukić, 2003, according to Nikić, Mitrovic, Travica, 2014). The present moment in agribusiness puts the spotlight on new strategies and a modern way of doing business, which actualizes a number of management issues, such as openness and willingness of managers to cope with numerous challenges. The leading global companies have realized that the greatest room for improvement does not lie only in improving the quality of products, but also in the field of human resources. Numerous studies show (Berso, Yammarino, 2006; Popper, Amit, 2009) that emotional and social competencies, intellectual flexibility and personality traits of managers are vital for achieving top results at work, especially in the sphere of management in different areas of business.

Modern organizations are made up of a large number of people. There is almost no workplace where people are isolated from each other, so the constant interaction between employees puts the skills of managers in the forefront, and managers, besides their professional competence, are increasingly required to be psychologically astute, flexible, to know how to control themselves and skillfully communicate with others, which are mostly the characteristics of emotional intelligence. Also, in the moments of crisis employees much easier accept the decisions and tasks from managers if they are in accordance with a realistic assessment of reality. How is this realistic approach to management being developed, and to which extent do personality and emotions affect the stability in management? The efforts of researchers are increasingly directed toward the study of all factors affecting productivity. On the one hand, it is known that the strength of managers' performance comes from their available power, expert knowledge, information, skills, different mechanisms of influence and relationships in an organization. On the other hand, personality and social and emotional skills of managers are often crucial for good performance. 


\section{Basic characteristics of emotional intelligence}

Numerous studies confirm that emotional intelligence can be used as an important construct for understanding the behavior at work (Mayer, Roberts, \& Barsade, 2008; O’Boyle, Humphrey, Pollack, Hawver, \& Story, 2010). The very concept of emotional intelligence (EI) has its roots in the concept of social intelligence that was developed in the early 20 s of $20^{\text {th }}$ century by the psychologist E.L. Thondike (1920). In his opinion, social intelligence includes interpersonal intelligence as the ability to penetrate into what motivates people, how and why people do things and how to successfully cooperate. The psychologists Mayer and Salovey (1990) were first who created the concept of emotional intelligence. They began with the original concept that included three types of processing emotional information: assessment and expression of emotions in ourselves and in others, regulation of emotions, the use of emotions for adaptive purposes. At the very beginning, this concept had mainly heuristic value because it tried to consolidate knowledge from different fields of psychology (Takšić, 1998; Mayer, Salovey, Caruso, 2002).

Later, Mayer and Salovey published the second updated version of the model of emotional intelligence (Mayer, Salovey, 1999, Mayer, Caruso, Salovey, 1999). Within the new model they proposed refinement of the definition of emotional intelligence adding thinking about feelings as an important segment. According to them, emotional intelligence involves the ability of rapid perception, assessment and expression of emotions; the ability to grasp and generate feelings to facilitate thinking; the ability to understand emotions and emotional knowledge; and the ability to regulate emotions in order to promote emotional and intellectual development (Takšić 1998, Mayer, Salovey 1996).

Numerous authors have continued their work, among them Bar-On (Bar-On, 2006; Bar-On, Parker, 2000). He is known for having developed one of the first systems for evaluation that uses the term - coefficient of emotional intelligence. He defines the purpose of emotional intelligence as the effective understanding of one's self and others for establishing good interpersonal relations, and adaptation to the environment for success in meeting the environmental demands. Bar-On believes that EQ can be developed throughout life and that emotional intelligence can be improved in order to enhance personal and professional life. Bar-On also believes that individuals with a higher coefficient of EQ are generally more successful in coping with environmental demands and pressures (Bar-On, Handley \& Fund, 2005). Goleman (1996) defined emotional intelligence as the ability to learn many practical skills, which consists of 5 elements: self-awareness, motivation, self-regulation, empathy, commitment in relationships. For the purposes of this work we used Emotional competence questionnaire (Takšić, Moharić, Munjas, 2006) constructed according to the model of Mayer and Salovey (1990), which estimates three aspects of emotional intelligence: the ability to perceive and understand emotions, the ability to express and label emotions, the ability to regulate emotions.

The main characteristics of emotions relate to physiological changes, subjective experience and emotional expression. Communication and adaptation are the basic 
functions of emotions by which the body is prepared for adaptive activity but also to receive and transmit communication messages. Facial expression that developed during evolution increases the likelihood of transmission and understanding of emotions. In addition, it has been shown that certain personality traits, such as selfobservation, openness to new experiences, extroversion, locus of control and empathy are predictive for successful recognition of emotions. Neuroticism is associated with poorer recognition of emotions (Takšić, 2001).

The ability to understand emotions refers to the observation of regularity of occurrence of certain emotions and general knowledge about emotions, when and how they occur, similarities and differences. Goleman emphasizes self-awareness as an important characteristic of emotional intelligence which refers to the understanding of one's own emotions as well as their own strengths, weaknesses, values and motives.

People with strong self-awareness are realistic in assessing their own and others' emotions (Goleman, Bojacis, Maki, 2006). The ability to regulate and manage emotions refers to the possibility of recognition and awareness of one's own emotions in different situations. The main challenge for leaders is to manage themselves. The most important task of any leader is, in Goleman's opinion, maintaining emotional hygiene or mastering their own emotions, because leaders are unable to handle other people's emotions if they do not first manage themselves. Control of emotions is a sign of social maturity and this ability has evolved to adapt an individual to different social situations (Takšić, 2001).

\section{Personality dimensions of managers and their importance for understanding the behavior at work}

Most often it is considered that a manager should be hard-working and working, smart, energetic and ambitious, communicative, with creative, positive strong, courageous and stable personality. However, the personality of a manager has the strongest influence on forming attitudes, values, thinking, perception, problem diagnosis, and thus determines the way of making decisions and taking actions. In this paper, we begin with the personality dimensions defined by Zuckerman (Zuckerman, 2002). In his opinion, personality traits can be described in two ways: as systems or dispositions in an individual to perceive situations in a certain way and respond in a consistent way in these situations, and as a review of the frequency and intensity of past events, including past states and overt behavior in the situations (Zuckerman, 1991). After continuous testing for a full understanding of some personality traits it is necessary to study all levels of its manifestation, considered Zuckerman. The best illustration of Zuckerman's psychobiological model is the explanation of thedimensions of neuroticism which is considered to be explained in terms of activation of the sympathetic nervous system. Zuckerman focused on the study and understanding of the nature and cause of the basic dimensions of personality. He developed a biological model known as Alternative five-factor model. We begin with the personality dimensions defined by Zuckerman (Zuckerman, 2002). We used a reduced scale of 50 items, on the recommendation of the author. 
The dimension Activity includes two types of items. The first group, according to Zuckerman, refers to the need for general activity. In people with high scores on this subscale impatience and anxiety appear in situations where there is no possibility to meet these needs. The second sub dimension refers to the tendency toward difficult and challenging tasks. These jobs are usually performed with a lot of energy and effort invested. Aggression and hostility refer primarily to the tendency toward verbal aggression, while the second group of items refers to the offensive, careless or antisocial behavior, revenge, malice and impatience with others.

Impulsive sensation seeking includes two lower-order factors. One refers to the tendency toward impulsive behavior, which is generally accompanied by an inability of planning. Another lower-order factor refers to the tendency to excitement and unpredictable situations, and the need for constant change and novelties.

Neuroticism - anxiety indicates emotional anxiety, tension, worry, fear, obsessive indecisiveness as well as sensitivity to criticism. Sociability includes two subcomponents. One part of the items within this dimension largely refers to enjoying parties and a large number of friends. The second part of the items focuses on the intolerance of social isolation in extroverts and the tendency toward solitary activities in introverts.In the last decades psychologists have documented through numerous studies that emotional intelligence can be used as an important construct for understanding the behavior at work.

Numerous studies have been done with the aim to find out what characteristics are necessary for successful work in the organization, especially the characteristics of managers. According to the results, communication, flexibility, emotional self-control, motivation, effectiveness in teamwork, leadership skills, as well as adequate intellectual functioning, expertise, knowledge and experience are at the forefront. More than half of these characteristics are in the domain of emotional intelligence, which is becoming increasingly important in the higher spheres of management.

Most often it is considered that managers should be strong, stable, courageous, positive and creative personalities, because personality traits rather talk about how managers cope in different situations, how they direct the energy and solve problems, what attitudes and values they have and how they perceive reality as a whole. In this sense, more and more authors speak about the importance of people, knowledge,skills and abilities in order to achieve top results in the uncertain business conditions of modern business, but also in the sphere of agribusiness.

In this paper, we examined the correlations and differences in emotional intelligence and personality traits depending on the managerial position of the respondents.

\section{Methods and materials}

Goals and objectives

The main goal of this study is to examine the difference between high-level and midlevel managers in agribusiness compared to lower managerial positions in terms of 
personality traits and emotional intelligence.

Hypotheses

General hypothesis: It is expected that there is a statistically significant difference between high-level and mid-level managers compared to lower managerial positions in terms of personality traits and emotional intelligence.

Sample: The research covered 240 respondents from Serbia. The structure of the sample is heterogeneous, consisting of employees and managers of both genders and various ages. This paper presents the results relating to the permanent staff of 125 managers in the Mercator Group trade chain of food industry.

\section{Instruments and variables}

To estimate emotional intelligence Emotional Competence Questionnaire was used, with 45 items. This is a shortened version of Emotional Intelligence Questionnaire UEK-136 (Takšić, Moharić, Munjas, 2006) constructed according to the theoretical model of Mayer and Salovey(1990), which estimates three aspects of emotional intelligence: the ability to perceive and understand emotions, the ability to express and label emotions and the ability to regulate emotions. All scales have satisfactory reliability in a variety of samples, from $\alpha=0,71$ to $\alpha=0,90$. This instrument was used in studies in Serbia (Nikić, Mitrovic, Travica, 2014; Nikic, Travica, Mitrovic, 2014; Nikic, Mitrovic, 2015), and showed good characteristics.

To estimate personality type Personality Questionnaire for estimating dominant personality traits was used, ZKPQ (Zuckerman, 2002). In this paper, the shortened scale of 50 items was used on the recommendation of the author. The dimensions of this questionnaire are: Activity (Act), Aggressiveness - hostility (Agg-Host), Impulsive sensation seeking (ImpSS), Neuroticism and Anxiety (N-Anx) and Sociability (Sy). The correlations on individual subscales (Zuckerman, 2002) were: for ImpSS (0.80), N - Anx (0.84), for Agg - Host (0.78), in Act (0.76), and Sy (0.83).

\section{Results and discussion}

\section{Connection between personality traits, emotional intelligence and managerial positions}

The connection between personality traits, emotional intelligence and managerial positions was examined by Pearson coefficients of the linear correlation on dimensions of emotional intelligence and personality dimensions with a level of managerial positions. 
Table 1. Pearson coefficient of linear correlation

\begin{tabular}{|l|l|l|}
\hline & & Managerial position \\
\hline Perceive and understand emotions - EQ & $\mathrm{r}$ & .073 \\
\hline Express and label emotions - EQ & $\mathrm{p}$ & .277 \\
\hline & $\mathrm{r}$ &. $\mathbf{3 6 0}(*)$ \\
\hline Regulate and manage emotions - EQ & $\mathrm{p}$ & .017 \\
\hline & $\mathrm{r}$ &. $\mathbf{4 6 5}(* *)$ \\
\hline Neuroticism- anxietyZKPQ & $\mathrm{p}$ & .000 \\
\hline & $\mathrm{r}$ & $-.283(* *)$ \\
\hline Impulsive sensation seeking - ZKPQ & $\mathrm{p}$ & .000 \\
\hline & $\mathrm{r}$ & -.080 \\
\hline Activity- ZKPQ & $\mathrm{p}$ & .230 \\
\hline & $\mathrm{r}$ & $\mathbf{. 1 6 8}(*)$ \\
\hline Sociability ZKPQ & $\mathrm{p}$ & .018 \\
\hline & $\mathrm{r}$ & .088 \\
\hline Aggression- hostility ZKPQ & $\mathrm{p}$ & .111 \\
\hline & $\mathrm{r}$ &.$- \mathbf{1 6 1}(*)$ \\
\hline
\end{tabular}

r-Pearson coefficient of linear correlation

p-level of significance: * Correlations significant at the 0.05 level ** Correlation significant at the 0.01 level

Source: Work of authors based on research Nikić, Stamatović, Sućeska, 2017;

Based on these results we can see that the managers in higher positions express and label their emotions better and also have better regulation and management of emotions and higher activity. With the increase in managerial positions the level of neuroticism and anxiety, as well as aggression, decreases.

\section{The differences in emotional intelligence and personality traits depending on managerial positions}

The differences in emotional intelligence and personality traits depending on managerial positions were examined by Canonical discriminat analysis. The criterion variable was a managerial position (the respondents were divided into two groups: higher-level managers and lower-level managers). A set of predictor variables consisted of factor scores on the principal components of the subscales of the questionnaire for assessing personality traits and the scores on the subscales of emotional intelligence.

Canonical discriminant analysis 
Table 2. Typical root, percentage of variance and canonical correlation

\begin{tabular}{|l|l|l|l|l|}
\hline Function & Typical root & Percentage of variance & Cumulative percentage & $\begin{array}{l}\text { Canonical } \\
\text { correlation }\end{array}$ \\
\hline 1 & .573 & 88.0 & 88.0 & .603 \\
\hline
\end{tabular}

Source: Work of authors based on research Nikić, Stamatović, Sućeska, 2017;

Table 3. Estimation of the significance of discriminant function

\begin{tabular}{|l|l|l|l|l|}
\hline Function & Wilks' Lambda & $\chi^{\mathbf{2}}$ & Number of degrees of freedom & $\mathbf{p}$ \\
\hline 1 & .589 & 44.428 & 8 & .007 \\
\hline
\end{tabular}

Source: Work of authors based on research Nikić, Stamatović, Sućeska, 2017;

The extracted discriminant function is statistically significant at a significance level of $p=0.007$ and the coefficient of canonical correlation $\mathrm{Rc}=0.603$, which means that the existence of difference between the groups of respondents is evident, and this difference is of moderate intensity.

Table 4.Matrix of the structure of discriminant function

\begin{tabular}{|l|l|}
\hline & Function \\
\hline & 1 \\
\hline Perceive and understand emotions - EQ & $\mathbf{. 3 7 0}$ \\
\hline Regulate and manage emotions - EQ & $\mathbf{. 3 3 5}$ \\
\hline Activity- ZKPQ & $\mathbf{. 2 9 9}$ \\
\hline Sociability - ZKPQ & $\mathbf{- . 2 2 8}$ \\
\hline Impulsive sensation seeking - ZKPQ & .192 \\
\hline Neuroticism- anxiety -ZKPQ & -.148 \\
\hline Express and label emotions - EQ & .148 \\
\hline Aggression- hostility ZKPQ & -.086 \\
\hline
\end{tabular}

Source: Work of authors based on research Nikić, Stamatović, Sućeska, 2017;

On the positive pole of the discriminant function there are the dimensions of emotional intelligence: perceiving and understanding emotions and regulation and management of emotions, as well as activity.

Sociability is on the negative pole.

Table 5.Centroides of groups

\begin{tabular}{|l|l|}
\hline \multirow{2}{*}{ position } & \\
\cline { 2 - 2 } & 1 \\
\hline higher & .406 \\
\hline lower & -.349 \\
\hline
\end{tabular}

Source: Work of authors based on research Nikić, Stamatović, Sućeska, 2017; 
Based on the values and direction of the group centroides we can see that the managers in a higher position are on the positive pole of the discriminant function, and the managers in a lower position are on the negative pole. This result means that the higher-level managers show a higher level of emotional intelligence in perceiving and understanding emotions, regulation and management of emotions, and also their personality trait named Activity is higher than in any other group of the respondents.

The respondents in lower managerial positions show higher sociability in relation to the higher-level managers. The changes which have occurred in the last decade in the sphere of business in our environment are more than dramatic. Some old ideas, especially on social security and the right to work have been replaced by the requirement that employees constantly prove their "good run" on the competitive and demanding market. The situation in the sphere of agribusiness is not easier due to numerous changes in the conditions of privatization, European integration and globalization of the market. On the other hand, companies are more than ever aware that emotional self-conscious and capable managers are necessary, especially high-level managers, in order to successfully lead teams and organizations through stressful and uncertain situations.

Previous studies show that emotional intelligence is one of the most significant characteristics of higher levels of leadership (Goleman, Bojacis, Maki, 2006). Goleman believes that today a new profile of leaders is necessary more than ever. Will a company be ready enough to survive the challenges of the future largely depends on whether its leaders, especially top managers, are ready to regulate their own emotions in the conditions of major changes. These authors argue that today we need emotionally intelligent leaders who know how to recognize, understand and manage their turbulent emotions and are able to think rationally even in the conditions of great crisis. At the highest levels of leadership positions, nearly $90 \%$ of the necessary competencies for success and advancement at work are emotional and social in their nature. It has also been shown that the knowledge of emotions and "coping with them" are especially important for managers because they work in special social context with constant interaction with employees and clients (Salovey, Mayer, 1990).

In the previous research Palmer et al (Palmer, Walls, Burgess, Stough, 2001) found that emotional intelligence was correlated with several characteristics of transformational leadership, which also suggests that it may be an important component of effective leadership. In their opinion, emotional intelligence is an increasingly popular measure for assessing effective leadership, as well as an important tool for developing leadership skills. It has been shown, in similar studies, that effective managers are able to understand their emotions and moods, but also thoseof employees and clients in everyday complex interactions (Manning, 2003).

Recent research has shown that emotional intelligence is positively correlated with job satisfaction and performance of employees, especially in business related to food (Sy, Tram, O’Hara, 2016). According to Birwatkar (2016), success in business is not a quantum leap, but rather an accumulation of small changes arising from the persistence, 
perseverance and passion to provide the best employee productivity in business with the help of emotional intelligence. The competencies of emotional intelligence are the key for moral development, as well as for general achievement and life success. It can be concluded that it is essential that companies create innovative programs and develop highly emotionally intelligent managers in order to achieve better results of employees (Altındağ, Kosedag, 2015).

The scale for measuring emotional intelligence (UEK-136, Takšić, Moharić, Munjas, 2006) has been used in other studies in Serbia. In the research from 2014 (Nikić, Travica, Mitrovic) the results showed that managers on all three dimensions of emotional intelligence achieved higher scores in relation to employees, suggesting that it is important that companies encourage managers to develop their emotional competence. When examining gender differences, it was shown that women achieved better results compared to male colleagues on all three scales of emotional intelligence, which creates room for women employees to better use their business potentials (Nikić, Mitrovic, 2015). This finding is consistent with the previous research on emotional intelligence (Day \& Carroll, 2004; Palmer, Gignac, Monocha, Stough, 2005).

Personality traits are considered very important for successful leadership, and Zuckersman's 5 dimensions (neuroticism, impulsive sensation seeking, activity, sociability and aggressiveness) provide important information about the level of leaders' energy, their resistance to stressful situations, emotional maturity, self-confidence. In this study, the leaders of higher level have higher activity, which indicates that they are actively engaged in business but also prone to challenging and difficult tasks. The leaders in lower positions are more sociable, which indicates that they have better communication with employees.

The quality of interaction in teams of employees is significantly influenced by emotional intelligence and personality of managers. The study from 2014 (Nikić, Mitrovic, Travica) showed that the respondents who had higher scores on all three dimensions of emotional intelligence showed higher activity and sociability and lower neuroticism and aggressiveness, which is of importance for teamwork. It was found that the respondents, who were more satisfied with their lives, were less neurotic and aggressive, and they better regulated and managed emotions. It was also found that people with high scores on emotional intelligence showed lower neuroticism and greater sociability (Nikić, Mirović, Travica, 2014). The research shows that there is a connection between emotional intelligence and personality traits of managers and their resistance to organizational changes (Vakola, Tsaousis, Nikolaou, 2004).

It has been obtained in this study that managers in higher positions achieve higher scores on emotional intelligence and are prone to an active attitude toward work and coping with the most difficult problems, which is in line with their duties. The lowerlevel managers show high sociability, which indicates that they are more focused on people, colleagues and end users, which is an important factor of job satisfaction as well as of the satisfaction of users and all those with whom managers come into contact. 


\section{Conclusion}

Leaders with their performance can enhance hostile feelings and antagonism, or, despite difficulties, optimism and realistic assessment of the problem. These two approaches, often present in practice, indicate a hidden but important dimension of leadership - the emotional effect of what the leader says and does. Most employees are mostly relying on the leader's opinion and attitude considering the significant role of the leader's decisions. On the other hand, the matters of emotion are not given sufficient attention, given that emotions are considered too personal, and discussion on them inappropriate or intrusive.

Although most people observe that the demeanor of leaders - and the way they act and affect the others - plays a significant role in every organization, the issues of emotional climate in the organization only recently have been given attention. However, research in the field of emotions shows that emotional intelligence is important for responsible leadership, and leaders who use their EI skills show better results at different levels of management. Understanding the important role of emotions in the workplace distinguishes the best leaders from others - not only in terms of tangible results such as increased business success and retention of high-productive people, but also in terms of the very important psychological criteria, such as a better mood, motivation and commitment.

In this, as in many other studies, managers in higher positions show a greater ability to recognize and "cope with their own and other people's emotions" which is a significant characteristic of leadership skills. Managers in higher positions also have a more active attitude to work and a greater willingness to solve the most difficult problems, while managers in lower positions focus on communication and people, which is, on the other hand, important for success of the communication processes in business.

New studies are needed in different sectors to help leaders to improve their leadership skills in the field of agribusiness. Besides professional competencies, not less important is the acquisition of social and emotional skills: communication, self-management, decision making, teamwork and interpersonal relationships.

It is also important to do systematic research on emotional competencies and personality traits of leaders in agribusiness at various levels, including different activities.

On the other hand, it is important to introduce innovative programs that enhance development of emotional and social competencies of managers in all areas of agribusiness.

\section{Literature}

1. Altındağ, E., Kösedağı, Y. (2015): The Relationship between Emotional Intelligence of Managers, Innovative Corporate Culture and Employee Performance. International Conference on Communication in Multicultural Society, Procedia - Social and Behavioral Sciences, Vol. 210, No. 2, pp. 270 - 
282, ScienceDirect, Moscow, Russia.

2. Bar-On, R. (2006): The Bar-On Model Of Emotional-Social Intelligence (ESI). Psicothema, Vol.18, pp. 13-25, University of Texas Medical Branch, Texas, USA.

3. Bar-on, R., Parker, J. A. (2000): Emotional and social intelligence: Insights from the Emotional Quotient Inventory (EQ-i). In R. Bar-On and J. D. A. Parker (Eds.), Handbook of emotional intelligence, pp. 363-388, Jossey-Bass, San Francisco, USA.

4. Bar-On, R., Handley, R., Fund, S. (2005): The Impact Of Emotional And Social Intelligence On Performance. In Vanessa Druskat, Fabio Sala, and Gerald Mount (Eds.), Linking emotional intelligence and performance at work: Current research evidence, pp. 3-19, Lawrence Erlbaum, Mahwah, New Jersey, USA.

5. Berson, Y., Yammarino, O. (2006): Attachment style and individual differences in leadership perceptions and emergence, Journal of Social Psychology, Vol. 146, No. 2, pp.165-82, Taylor, Francis, Philadelphia, USA.

6. Birwatkar, V. (2016): Echoes of Emotions in Organizational Learning, Lambert, Academic Publishing. Moldova.

7. Cvijanović, D., Trandafilović, S., Imamović, N. (2013): Marketing concept in terms of agricultural enterprises development in transitional countries. Economics of Agriculture, No. 1, pp. 113-123, Institute of Agricultural Economic, Belgrade, Serbia.

8. Cvijanović, G., Dozet, G.,Cvijanović, D. (2013): Menadžment u organskoj biljnoj proizvodnji. Monografija. Institut za ekonomiku poljoprivrede, Belgrade, Serbia.

9. Day, A. L., Carroll, S. A. (2004): Using an ability-based measure of emotional intelligence to predict individual performance, group performance, and group citizenship behaviours, Personality and Individual Differences, The Official Journal of the International Society for the Study of Individual Differences (ISSID) 36, pp. 1443-1458, Western University, London, Ontario, Canada.

10. Čukić, B. (2003): Psihologija rada-usklađivanje čoveka i posla, Istraživački centar za industrijski menadžment plus, Kruševac, Serbia.

11. Goleman, D. (1996): Emocionalna inteligencija, Geopoetika, Belgrade, Serbia.

12. Goleman, D. Bojacis, R. Maki, E. (2006): Emocionalna inteligencija u liderstvu, Adidžes, Novi Sad, Serbia.

13. Manning, T. (2003). Leadership across cultures: Attachment style influences. Journal of Leadership and Organizational Studies, 9, pp. 20-30, SAGE Publishing, London, UK.

14. Mayer, J. D., Salovey, P., Caruso, D. R. (2002): Mayer-Salovey-Caruso Emotional Intelligence Test (MSCEIT): User's manual, Multi-Health Systems, Toronto, Canada. 
15. Mayer, D. \& Salovey, P. (1990): Emotional intelligence, Imagination, Cognition and Personality, vol. 9(3), pp. 185-211, Baywood Publishing Co., Inc San Francisco, USA.

16. Mayer, J. D., Caruso, D. R., Salovey, P. (1999): Emotional Intelligence Meets Traditional Standards For Intelligence, Intelligence, Vol. 27, pp. 267-298. University of New Hampshire, USA.

17. Nikić, G., Mitrović, M., Travica,V. (2014): The Quality Of Business Communications Depending On The Attachment Style, Social Emotional Competencies And Personality Traits, Industrija, Vol. 42, No. 4, pp. 79-97, Institut ekonomskih nauka, Belgrade, Serbia.

18. Nikic, G., Travica,V., Mitrovic, M. (2014): Differences Between Employees And Managers Regarding Socio-Emotional Competencies, Serbian Journal of Management, Vol. 9, No. 2, pp. 281-292, University in Belgrade, Bor, Serbia.

19. Nikić, G., Mitrović, M. (2015): Emotional Intelligence Of The Employees In Serbia - Gender Differences. Journal Of Women's Entrepreneurship And Education, JWE, 1-2 pp. 67-85, Institut ekonomskih nauka, Belgrade, Serbia.

20. Mayer, J. D., Roberts, R. D., Barsade, S. G. (2008): Human abilities: Emotional intelligence, Annual Review of Psychology, Vol. 59, pp. 507-536, University of Pennsylvania, USA.

21. O’Boyle, E. H., Humphrey, R. H., Pollack, J. M., Hawver, T. H., Story, P. A. (2010): The Relation Between Emotional Intelligence And Job Performance: A Meta-Analysis. Journal Of Organizational Behavior, DOI: 10.1002/job.714, John Wiley \& Sons, New York, USA.

22. Palmer, B. R., Gignac, G., Monocha, R., Stough, C. (2005): A psychometric evaluation of the Mayer-Salovey-Caruso Emotional Intelligence Test version 2.0, Intelligence, Vol. 33, pp. 285-305, Elsevier, The Univesity of Western Australia, Australia.

23. Palmer, B., Walls, M., Burgess, Z., Stough, C. (2001): Emotional intelligence and effective leadership, Leadership \& Organization Development Journal, vol. 22 No. 1, pp.5-10, Published by MCB UP Ltd, UK.

24. Popper, M., Amit, K. (2009): Influence of Attachment Styile on Major Psychological capacites to Lead,The Journal of Genetic Psychology, Vol. 170, No. 3, pp. 244-267, Publisher: Taylor \& Francis, UK.

25. Repar, L., NJaro, M., Par,V. (2012): Management and leadership in agriobusiness companies, Journal of Central Europan Agriculture, Vol. 13, No. 1, pp. 109-1022, Publisher: Journal of Central European Agriculture, Croatia.

26. Sy,T.,Tram, S.,O’Hara, L. (2006): Relation of employee and manager emotional intelligence to job satisfaction and performance. Journal of Vocational Behavior Volume 68, Issue 3, pp 461-473. Elsevier, UK.

27. Takšić, V., Moharić, T., Munjas, R. (2006): Emocionalna inteligencija: teorija, 
operacionalizacija, primjena i povezanost s pozitivnom psihologijom, Filozofski fakultet, Rijeka, Croatia.

28. Takšić, V. (2001): Teorijsko ishodište i modeli emocionalne inteligencije, Glasje, pp. 211-225, Faculty of Philosophy, Rijeka, Croatia.

29. Takšić, V. (1998): Validation of the Emotional Intelligence Construct, Unpublished doctoral dissertation, University of Zagreb, Zagreb, Croatia.

30. Thondike, E.L.(1920): Reliability and Significance of Tests of Intelligence, The Journal of Educational Psychology, vol. XI, American Psychological Association, USA.

31. Vakola, M.,Tsaousis,I.,Nikolaou,I. (2004): The role of emotional intelligence and personality variables on attitudes toward organisational change, Journal of Managerial Psychology, Vol. 19 No. 2, pp.88-110. West Yorkshire, UK.

32. Zuckerman, M., Michael K., Thornquist, M., Kiers, H. (1991): Five (or three) robust questionnaire scale factors of personality without culture, Personality and Individual Diferences , Vol. 12, pp. 929-941, Elsevier, UK,

33. Zuckerman, M. (2002): Zuckerman-Kuhlman Personality Questionnaire (ZKPQ): An alternative five factorial model. In B. DeRaad, and M. Peru-sini (Eds.), Big Five Assessment, pp. 377 - 396, Hogrefe and Huber Publishers, Seattle, USA. 


\title{
EMOCIONALNE KOMPETENCIJE I OSOBINE LIČNOSTI MENADŽERA U SAVREMENOM AGROBIZNISU
}

\author{
Gordana Nikic ${ }^{4}$, Ljubiša Stamatovič ${ }^{5}$, Azra Sućeska ${ }^{6}$
}

\begin{abstract}
Apstrakt
Glavni cilj ovog rada je utvrđivanje razlika između menadžera u agrobiznisu, srednjeg $i$ visokog ranga u odnosu na niže menadžerske pozicije u pogledu osobina ličnosti i emocionalne inteligencije. Istraživanje obuhvata 240 ispitanika iz Srbije. Struktura uzorka je heterogena, čine ga zaposleni i rukovodioci oba pola i različitog uzrasta. $U$ ovom radu biće prikazani rezultatikoji se odnose na 125 menadžera stalno zaposlenih u trgovinskom lancu prehrambene industrije Merkator Group. Za procenu emocionalne inteligencijei korišćen je Upitnik emocionalne kompetentnosti (Takšić, Moharić, Munjas, 2006), aza procenu tipa ličnosti korišćen je Upitnik za procenu dominantnih osobina ličnosti ZKPQ (Zuckerman, 2002). Dobijeni rezultati ukazuju da menadžeri na višim pozicijama pokazuju viši nivo emocionalne inteligencije kada je upitanju uočavanje i razumevanje emocija, njihova regulacija i upravljanje njima, takođe im je izraženija osobina ličnosti nazvana Aktivitet u odnosu na drugu grupu ispitanika. Ispitanici koji su na nižim menadžerskim pozicijama pokazuju izraženiju socijabilnost u odnosu na menadžere sa viših pozicija.
\end{abstract}

Ključne reči: menadžeri, agrobiznis, profil ličnosti, emocionalna inteligencija

4 Docent, dr Gordana Nikić, Univerzitet Singidunum, Fakultet za turizam I hotelijerski menadžment, Kumodraška Ulica br. 261a, 11000 Beograd, Srbija, Telefon: +381 63 7365817, E-mail: gnikic@, singidunum.ac.rs

5 Master, Ljubiša Stamatović, doktorske studije, Univerzitet Union, Beogradska Bankarska Akademija, Zmaj Jovina Ulica br. 3, 11000 Beograd, Srbija, Telefon: +381 612453 486, E-mail: ljubisastamatovic@gmail.com

6 Docent, dr Azra Sućeska, Univerzitet SUSU-SOUTH Ural, Rusija, Telefon: +381 66234304 , E-mail: azra.hanic@,bba.edu.rs

EP 2017 (64) 1 (97-111) 
ECONOMICS OF

AGRICULTURE

\section{CONTENT}

1. Željko Anđelković, Aleksandra Dragin, Sanja Božić, Kristina Košić

EMOTIONAL EXHAUSTION AND JOB SATISFACTION OF TOUR GUIDES IN RURAL AREAS . . . . . . . . . . . . . . 11

2. Sanja Đukić, Danica Glavaš-Trbić, Nikola Banjac

MANAGEMENT PROBLEMS OF RURAL DEVELOPMENT IN FRUŠKA GORA . . . . . . . . . . . . . . . . . . . . 27

3. Ivana Ilić, Bojan Krstić, Sonja Jovanović

ENVIRONMENTAL PERFORMANCES OF AGRICULTURE IN THE EUROPEAN UNION COUNTRIES . . . . . . . . . . . . . 41

4. Nataša Kljajić, Jonel Subić, Zorica Sredojević

PROFITABILITY OF RASPBERRY PRODUCTION

ON HOLDINGS IN THE TERRITORY OF ARILJE. . . . . . . . . . . 57

5. Aleksandar Maksimović, Zoran Grgić, Ferhat Ćejvanović

MULTI-ATTRIBUTE ANALYSIS OF ORCHARD ACCORDING

TO THE INTEGRATED PRODUCTION CONCEPT . . . . . . . . . . 69

6. Ozrislava Milinković, Branislav Jakić, Slobodan Vuksanović,

Dragana Macura, Milica Šelmić

MULTI- CRITERIA DECISION BASED APPROACH

TO SELECTING THE TYPE OF INDUSTRIAL HALLS

USED IN FOOD INDUSTRY $\ldots \ldots \ldots \ldots$. . . . . . . . . . 81

7. Gordana Nikić, Ljubiša Stamatović, Azra Sućeska

EMOTIONAL COMPETENCIES AND PERSONALITY

TRAITS OF MANAGERS IN MODERN AGROBUSINESS. . . . . . . .97

8. Vladimir Obradović, Nemanja Karapavlović

FINANCIAL REPORTING OF COMPREHENSIVE INCOME

IN THE FOOD AND BEVERAGE SECTOR

IN THE REPUBLIC OF SERBIA . . . . . . . . . . . . . . 113 
9. Aleksandar Ostojić, Nebojša Savić, Željko Vaško

CONSUMER ATTITUDES

ON BUYING FISH IN BANJA LUKA . . . . . . . . . . . . . . . 129

10. Radivoj Prodanović, Boris Kuzman, David Jovović, Lazar Ozegović

MARKET AND TRADE OF ORGANIC FRUITS IN SERBIA $\ldots . . .141$

11. Predrag Vukadinović, Aleksandar Damnjanović, Ljiljana Dimitrijević

ANALYSIS OF THE SALES AND INCOMES BETWEEN

DIFFERENT CATEGORIES OF AGRICULTURAL PRODUCTS . . . 157

12. Jugoslav Aničić, Svetlana Vukotić, Goran Maksimović

THE POSSIBILITIES AND LIMITATIONS

OF ENTREPRENEURSHIP DEVELOPMENT

IN AGRICULTURE IN SERBIA . . . . . . . . . . . . . . 171

13. Željko Bjelajac, Marijana Dukić - Mijatović, Joko Dragojlović

FOOD SAFETY AS ONE OF THE MAIN SAFETY $P$

REOCCUPATIONS OF A MODERN MAN . . . . . . . . . . . . . 191

14. Milan Bradić, Ljiljana Kosar, Lukrecija Djeri, Svetlana Vukosav, Vuk Garača

ECO-LABELLING OF ACCOMMODATION FACILITIES

AND ITS PERCEPTION BY RURAL TOURISTS:

CASE STUDY OF VOJVODINA . . . . . . . . . . . . . . 205

15. Vaso Jegdić, Iva Škrbić, Srđan Milošević

MODELS OF ENTREPRENURSHIP DEVELOPMENT

IN RURAL TOURISM DESTINATIONS IN VOJVODINA . . . . . . . 221

16. Duško Kuzović

MUSEUM OF VERNACULAR ARCHITECTURE OF WESTERN SERBIA

- Representative curtilages of the area surrounding middle

course of the river Drina and Podgorina . . . . . . . . . . . 239

17. Branko Mihailović, Zoran Simonović, Nikola Ćurčić

AGRICULTURAL RESOURCES AND DEVELOPMENT

PRIORITIES OF THE MUNICIPALITY OF STARA PAZOVA. . . . . 259

18. Radmilo Nikolić, Aleksandra Fedajev, Vidoje Stefanović, Silvana Ilić

THE AGRICULTURE SECTOR IN WESTERN BALKANS

- SOME CHARACTERISTICS OF DEVELOPMENT. . . . . . . . . . 275

19. Vladimir Njegomir, Rajko Tepavac, Nenad Ivanišević

ALTERNATIVE SOURCES OF FINANCING

ENTREPRENEURIAL UNDERTAKINGS IN AGRICULTURE . . . 295

Economics of Agriculture, Year 64, No. 1 (1-404) 2017, Belgrade 
20. Daniela Nuševa, Kristina Mijić, Dejan Jakšić

THE PERFORMANCES OF COFFEE PROCESSORS

AND COFFEE MARKET IN THE REPUBLIC OF SERBIA . . . . . . 307

21. Svetlana Roljević Nikolić, Predrag Vuković, Biljana Grujić

MEASURES TO SUPPORT THE DEVELOPMENT OF ORGANIC

FARMING IN THE EU AND SERBIA . . . . . . . . . . . . 323

22. ŽeljkoVojinović, Vera Zelenović, DragoCvijanović

PROGRAM OF STATE SUPPORT

TO AGRICULTURAL CREDITING. . . . . . . . . . . . . . . . 339

23. Nikola Vuksanović, Dragan Tešanović, Bojana Kalenjuk,

Milijanko Portić, Marija Knežević

SOCIO-DEMOGRAPHIC CHARACTERISTICS

AS DETERMINANTS OF DIFFERENCES

IN PERCEPTION OF LOCAL GASTRONOMY . . . . . . . . . . . . 359 